\title{
STRUKTUR DAN KEPADATAN VEGETASI MANGROVE DI TELUK KUPANG
}

\author{
Rusydi'1), (hwan ${ }^{2)} \&$ Suaedin $^{2)}$ \\ 1)Prodi Agrobisnis Perikanan Faperik Univ. Muhammadiyah Kupang \\ 2)Prodi Pend. Biologi FKIP Univ. Muhammadiyah Kupang
}

Diterima tanggal: 22 Januari 2015; Diterima setelah perbaikan: 29 April 2015; Disetujui terbit tanggal 8 Juni 2015

\begin{abstract}
ABSTRAK
Vegetasi mangrove merupakan komunitas tumbuhan yang tumbuh di zona pasang surut di sepanjang garis pantai dan dipengaruhi oleh kualitas lingkungan. Meningkatnya kebutuhan manusia menyebabkan banyaknya hutan mangrove yang ditebang, diubah untuk berbagai kepentingan seperti pertambakan, pemukiman dan fasilitas-fasilitas pelabuhan. Teluk Kupang memiliki wilayah pesisir yang cukup kaya sumberdaya, salah satunya adalah hutan mangrove.Tujuan penelitian ini adalah untuk mengetahui jenis dan nilai kerapatan, frekwensi, dominansi dan INP mangrove di Teluk Kupang Pengambilan data menggunakan metode Petak Contoh (Transect Line Plot) dengan menghitung jumlah spesies (pohon, anakan dan semai), jumlah individu masing-masing spesies, persentase tutupan, lingkar batang dan menganalisis untuk mendapatkan nilai kerapatan, frekwensi, dominansi dan INP(Indeks Nilai Penting). Hasil penelitian menunjukkan bahwa pada 4 (empat) lokasi pengamatan, ditemukan sebanyak 11 jenis mangrove. Adapun 11 jenis mangrove yang ditemukan adalah; Rhizopora apiculata, Rhizopora mucronata, Rhizopora stylosa, Burguiera gymnorrhiza, Osbornia octodanta, Avicennia officinalis, Avicennia marina, Scyphiphora hydrophyllaceae, Lumnitzera racemosa, Sonneratia alba dan Aegiceras corniculatum. Jenis mangrove yang memiliki indeks nilai penting tertinggi untuk tingkatan pohon yaitu Rhizopora mucronata (INP :299,6) dan terendah adalah Rhizopora stylosa (INP : 18,5), untuk tingkatan pancang/anakan jenis mangrove yang memiliki indeks nilai penting tertinggi sekaligus terendah adalah Rhizopora apiculata (INP : 202 dan 39,62). Sedangkan untuk tingkatan semai, jenis yang memiliki indeks nilai penting tertinggi yaitu Soneratia alba (INP : 174)dan terendah adalah Burguiera gymnorrhiza dan Scyphiphora hydrophyllaceae (INP : 11,80).
\end{abstract}

Kata kunci: Struktur, Kepadatan, Vegetasi mangrove, Teluk Kupang

\section{ABSTRACT}

Mangrove vegetation is plant communities that grows in tidal zonealong the coastline and affected by the quality of the environment. Increased human needs caused many mangrove forests felled, made for various purposes such as aquaculture, settlement and port facilities. Kupang Bay has a fairly rich coastal areas of resources, one of which is a mangrove forest. The purpose of this research to know the type and the value of the density, frequency, dominance and Important Value Index (IVI) mangroves in Kupang Bay. Retrieving data using Transect Line Plot method, by counting the number of species (trees, saplings and seedlings), the number of individuals of each species, percent cover, trunk circumference and analyzed to obtain the value of density, frequency, dominance and IVI. The results showed that the 4 (four) where observation, found as many as 11 species. These results are in contrast to previous studies there are 14 types. The 11 mangrove species found are; Rhizopora apiculata, Rhizopora mucronata, Rhizopora stylosa, Burguiera gymnorrhiza, Osbornia octodanta, Avicennia officinalis, Avicennia marina, Scyphiphora hydrophyllaceae, Lumnitzera racemosa, Sonneratia alba and Aegiceras corniculatum. Mangrove species that has an index value of the highest importance to the level of the tree that is Rhizopora mucronata (IVI: 299,6) and the lowest Rhizopora stylosa (IVI : 18,5), for stake levels / seedlings types of mangrove that had the highest importance value index is the lowest at the same time Rhizopora apiculata (IVI : 202 and 39,62). As for the seedling stage, the kind that has the highest importance value index Soneratia alba (IVI : 174) and the lowest Burguiera gymnorrhiza and Scyphiphora hydrophyllaceae (IVI : 11,80).

\section{Keywords: Structure, Density, Mangrove Vegetation, Kupang Bay}

\section{PENDAHULUAN}

Mangrove merupakan contoh ekosistem yang banyak ditemui di sepanjang pantai tropis dan estuari. Ekosistem ini memiliki fungsi sebagai penyaring bahan nutrisi dan penghasil bahan organik, serta berfungsi sebagai daerah penyangga antara daratan dan lautan. Bengen (2003) menyatakan bahwa hutan mangrove memiliki fungsi dan manfaat, antara lain; sebagai peredam gelombang dan angin badai, pelindung dari abrasi, penahan lumpur dan perangkap sedimen; penghasil sejumlah besar detritus dari daun dan pohon mangrove; daerah asuhan (nursery grounds), daerah mencari makan (feeding grounds) dan daerah pemijahan (spawning grounds) berbagai jenis ikan, udang, dan biota laut lainnya; penghasil kayu untuk bahan konstruksi, kayu bakar, bahan baku arang, dan bahan baku kertas (pulp); pemasok larva ikan, udang, dan biota laut lainnya; dan sebagai tempat pariwisata.

Ekosistem mangrove dapat tumbuh dengan baik pada zona pasang-surut di sepanjang garis pantai daerah tropis seperti laguna, rawa, delta, dan muara sungai. Ekosistem mangrove bersifat kompleks dan dinamis tetapi labil (Kusmana, 1995). Faktor-faktor yang mempengaruhi pembagian zonasi terkait dengan respons jenis tanaman terhadap keadaan tanah, terpaan ombak, pasang-surut dan salinitas serta kombinasi dari kondisi kimia dan fisik setempat. Seperti kondisi tanah berpengaruh dalam membentuk zonasi penyebaran tanaman dan hewan seperti perbedaan spesies kepiting pada kondisi tanah yang berbeda (Irwanto, 2006). 
Watson (1928) dalam Kusmana (1995) berpendapat bahwa hutan mangrove dapat dibagi menjadi lima bagian berdasarkan frekuensi air pasang, yaitu; zonasi yang terdekat dengan laut, akan didominasi oleh Avicennia spp dan Sonneratia spp, tumbuh pada lumpur lunak dengan kandungan organik yang tinggi. Avicennia spp tumbuh pada substrat yang agak keras, sedangkan Avicennia officinalis tumbuh pada substrat yang agak lunak; zonasi yang tumbuh pada tanah kuat dan cukup keras serta dicapai oleh beberapa air pasang. Zonasi ini sedikit lebih tinggi dan biasanya didominasi oleh Bruguiera cylindrica; ke arah daratan lagi, zonasi yang didominasi oleh Rhyzophora mucronata dan Rhyzophora apiculata. Jenis Rhyzophora mucronata lebih banyak dijumpai pada kondisi yang agak basah dan lumpur yang agak dalam. Pohon-pohon yang dapat tumbuh setinggi $35-40 \mathrm{~m}$. Pohon lain yang juga terdapat pada hutan ini mencakup Bruguiera parviflora dan Xylocarpus granatum; hutan yang didominasi oleh $B$. parviflora kadang-kadang dijumpai tanpa jenis pohon lainnya; hutan mangrove di belakang didominasi oleh $B$. gymnorrhiza.

Teluk Kupang memiliki wilayah pesisir yang cukup kaya sumberdaya alamnya, salah satunya adalah hutan mangrove. Dahulunya areal hutan mangrove ini cukup luas, namun berbagai aktifitas masyarakat seperti penebangan jenis-jenis flora mangrove oleh penduduk di sekitarnya untuk keperluan kayu bakar, dan kebutuhan rumah tangga lainnya sehingga menyebabkan area ini semakin berkurang luasan hutan mangrovenya (Kusuma \& Suhendra, 2006). Rusydi, et al. (2010) melaporkan bahwa di Teluk
Kupang ditemukan 14 Jenis mangrove.Namun seiring perjalanan waktu serta adanya aktivitas manusia disekitar vegetasi mangrove, sehingga perlu dilakukan survey/penelitian untuk mendapatkan data dan informasi tentang vegetasi mangrove di Teluk Kupang. Tujuan penelitian ini adalah untuk mengetahui jenis dan nilai kerapatan, frekwensi, dominansi dan INP mangrove di Teluk Kupang

\section{METODE PENELITIAN}

\section{Waktu dan Tempat}

Penelitian ini dilaksanakan selama 3 (tiga) bulan, terhitung sejak bulan Mei hingga Juli 2014, di Perairan Teluk Kupang. Secara administratif, lokasi penelitian berada pada wilayah Bolok Kecamatan Kupang Barat Kab. Kupang dan Pulau Semau Kabupaten Kupang. Dalam pelaksanaannya menggunakan alat bantu Global Positioning System (GPS). Adapun lokasi pengamatan sebagaimana disajikan pada Gambar 1.

Pengambilan data mangrove menggunakan metode Petak Contoh (Transect Line Plot) mengacu pada Kepmen LH Nomor 201 Tahun 2004. Pengambilan data jenis mangrove pada setiap zona vegetasi mangrove menggunakan garis transek, dengan petak contoh ( $p l o t)$ berbentuk bujur sangkar dengan ukuran 10x10 m (untuk tingkatan pohon), ukuran 5x5 m (untuk tingkatan anakan), ukuran $1 \times 1 \mathrm{~m}$ (untuk tingkatan semai) sebanyak 3 petak contoh dengan jarak plot pada setiap transek $50 \mathrm{~m}$. Data yang diperoleh adalah jenis mangrove, jumlah pada masing-masing jenis

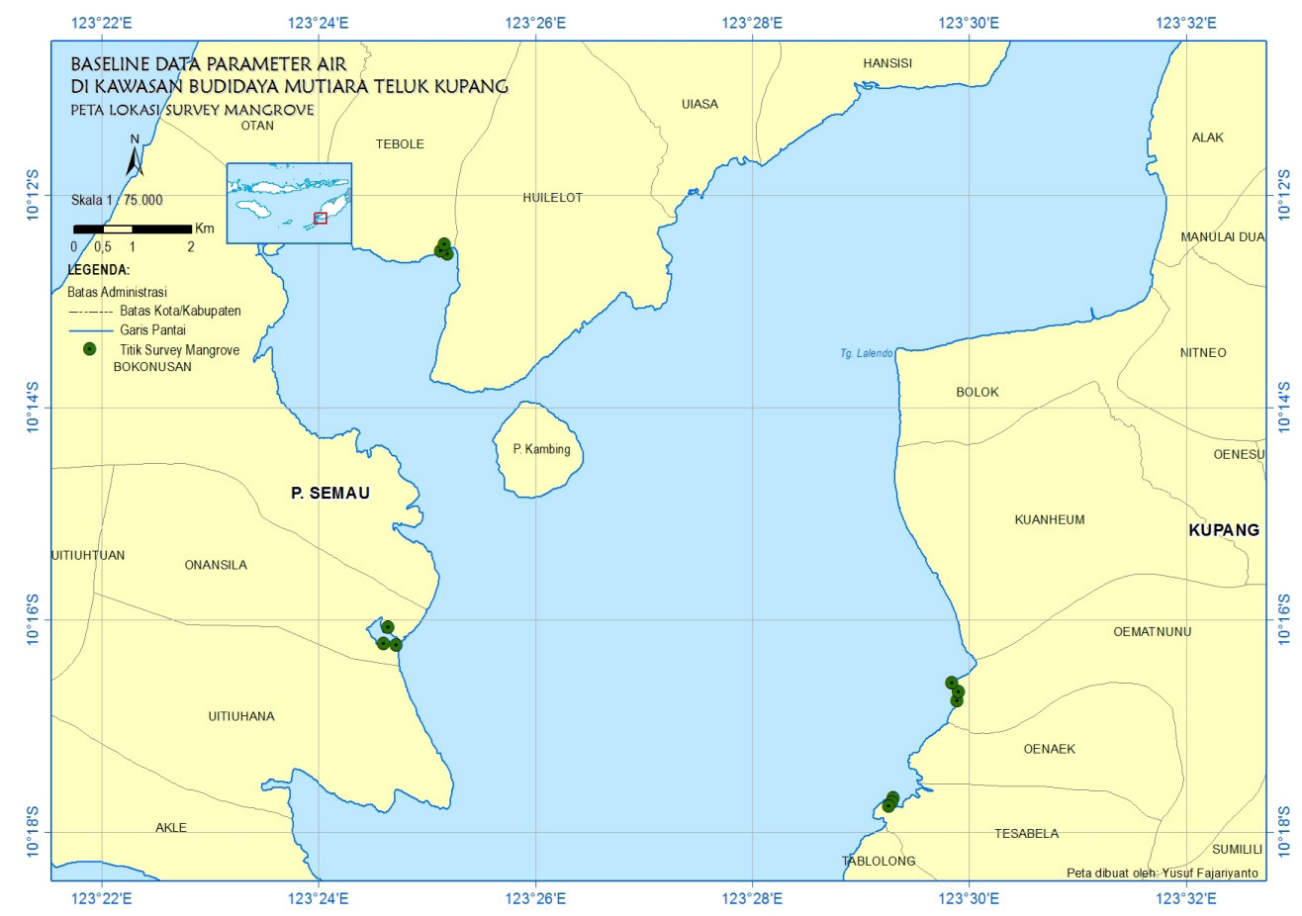

Gambar 1. Lokasi Penelitian dan titik pengamatan. 
mangrove, lingkar batang, luas tutupan (kanopi) untuk masing-masing tingkatan (pohon, anakan dan semai). Selanjutnya dilakukan identifikasi dan analisis data menggunakan rumus berikut (Bengen, 2003);

Analisis Kerapatan, dihitung menggunakan rumus sebagai berikut ;

$$
\begin{aligned}
& \text { Kerapatan }(K)=\frac{\text { Jumlah individu }}{\text { Luas petak contoh }} \quad \ldots \ldots \ldots \ldots \ldots \ldots \ldots \ldots \ldots \ldots \ldots \ldots \\
& \text { Kerapatan relatif }(K R)=\frac{\text { Kerapatan suatu jenis }}{\text { Kerapatan total seluruh jenis }} \times 100 \%
\end{aligned}
$$

Analisis Frekwensi, dihitung menggunakan rumus sebagai berikut ;

$$
\begin{aligned}
& \text { Frekwensi }(F)=\frac{\text { Jumlah plot ditemukan suatu spesies }}{\text { Jumlah selumh plot }} \\
& \text { Frekwensi relatif }(F R)=\frac{\text { Frekwensi suatu jenis }}{\text { Frekwensi seluruh jenis }} \times 100 \%
\end{aligned}
$$

Nilai Dominasi, dihitung menggunakan rumus sebagai berikut;

$$
\begin{aligned}
& \text { Dominasi }(D)=\frac{\text { Luas bidang suatu spesies }}{\text { Luas plot }} \ldots \ldots \ldots \ldots \ldots \ldots \ldots \ldots \\
& \text { Dominasi relatif }(D R)=\frac{\text { Dominasi suatu jenis }}{\text { Dominasi total seluruh jenis }} \times 100 \%
\end{aligned}
$$

Indeks Nilai Penting (INP), dihitung menggunakan rumus sebagai berikut ;

$\mathrm{INP}=\mathrm{KR}+\mathrm{FR}+\mathrm{DR}$ (untuk tingkatan vegetasi pohon)

INP $=$ KR + FR (untuk tingkatan vegetasi anakan dan semai)

\section{HASIL DAN PEMBAHASAN}

\section{Struktur Vegetasi Mangrove}

Pengambilan data jenis dan penyusun vegetasi mangrove di Teluk Kupang dilakukan pada 4 (empat) lokasi pengamatan yakni Desa Tesabela, Oematnunu, Oenansila dan Tebole. Pada masing-masing lokasi terdapat 3 (tiga) stasiun dan pada masing-masing stasiun terdapat 3 (tiga) titik/plot pengamatan. Adapun data yang diperoleh pada 4 (empat) lokasi pengamatan, sebagaimana disajikan pada tabel 1 berikut ini.

Berdasarkan data pada tabel 1 menunjukkan bahwa jenis-jenis tertentu ditemukan pada semua lokasi pengamatan, namun ada pula jenis lain yang hanya ditemukan pada titik/plot pengamatan tertentu saja. Secara keseluruhan terdapat 11 (sebelas) spesies mangrove yang terdapat pada 4 (empat) lokasi pengamatan. Proses identifikasi jenis-jenis mangrove menggunakan buku; Noor, et al. (1999). Adapun jenisjenis mangrove yang diperoleh disajikan pada Gambar 2.

\section{Analisis Kerapatan, Frekuensi dan Dominansi}

\section{a. Tesabela}

Pengambilan data penelitian di Tesabela dilakukan pada 3 (stasiun) pengamatan, yakni pada koordinat $10,29552^{\circ}$ LS, $123,48757^{\circ}$ BT (Tesabela
1), $10,29585^{\circ} \mathrm{LS}, 123,48721^{\circ}$ BT (Tesabela 2) dan $10,29755^{\circ}$ LS, $123,48693^{\circ}$ BT (Tesabela 3). Hasil analisis kerapatan, frekuensi dan dominansi jenis-jenis mangrove di Tesabela disajikan pada tabel 2 .

Berdasarkan data tabel 2, untuk tingkatan pohon darijenis Rhizophora mucronatamemilikinilaikerapatan tertinggi (1.200 ind/ha) dan kerapatan relatif (69,36\%), tingkatan anakan/pancang dari jenis Sonneratia alba, nilai kerapatan tertinggi (300 ind/ha) dan kerapatan relatif $(100 \%)$, tingkatan semai Sonneratia alba nilai kerapatan tertinggi (10.330 ind/ha) dan kerapatan relatif $(99,65 \%)$. Sedangkan nilai frekwensi berkisar antara 0,33-1, dengan frekwensi relatif yang beragam. Hasil analisis dominansi menunjukkan bahwa jenis Osbornia octodanta memiliki nilai dominansi jenis dan relatif tertinggi $21,27(43,88 \%)$ dan paling rendah dari jenis Aegiceras corniculatum sebesar 0,67 (2,09\%).

\section{b. Oematnunu}

Pengambilan data penelitian di Oematnunu dilakukan pada 3 (stasiun) pengamatan, yakni pada koordinat $10,27598^{\circ} \mathrm{LS}, 123,49821^{\circ}$ BT (Oematnunu 1), $10,27809^{\circ} \mathrm{LS}, 123,49813^{\circ} \mathrm{BT}$ (Oematnunu 2) dan $10,27960^{\circ}$ LS, $123,49827^{\circ}$ BT (Oematnunu 3). Hasil analisis kerapatan, frekuensi dan dominansi jeni-jenis mangrove di Oematnunu disajikan pada tabel 3 berikut.

Berdasarkan data di atas menunjukkan bahwa jenis Rhizophora mucronata memiliki nilai kerapatan tertinggi untuk tingkatan pohon(1.270 ind $\left./ \mathrm{m}^{2}\right)$ dan kerapatan relatif $(57,58 \%)$, tingkatan anakan/pancang dari jenis Sonneratia alba memiliki nilai kerapatan tertinggi (430 ind/ha) dan kerapatan relatif $(81,76 \%)$ serta tingkatan semai dari jenis Avicennia marina dengan nilai kerapatan tertinggi (47.800 ind/ha) dan kerapatan relatif $(85,97 \%)$. Sedangkan untuk nilai frekwensi berkisar antara 0,33 - 1 dan frekwensi relatif yang beragam. Hasil analisis dominansi menunjukan jenis Rhizophora mucronata memiliki nilai dominansi jenis dan relatif tertinggi sebesar 109,9 (65,38\%) sedangkan terendah dari jenis Rhizophora apiculata dengan nilai dominansi jenis dan relatif sebesar 1,63 $(2,91 \%)$.

\section{c. Oenansila}

Pengambilan data penelitian di Oenansila dilakukan pada 3 (stasiun) pengamatan, yakni pada koordinat $10,27041^{\circ}$ LS, $123,41009^{\circ}$ BT (Oenansila 1), $10,26824^{\circ}$ LS, $123,41037^{\circ}$ BT (Oenansila 2) dan $10,27067^{\circ} \mathrm{LS}, 123,41193^{\circ} \mathrm{BT}$ (Oenansila 3). Hasil analisis kerapatan, frekuensi dan dominansi jeni-jenis mangrove di Oenansila disajikan pada tabel 4 berikut.

Berdasarkan data tabel 4 bahwa untuk tingkatan pohon dari jenis Rhizophora mucronata memiliki 
Tabel 1. Jenis-jenis mangrove yang ditemukan pada 4 (empat) lokasi penelitian

\begin{tabular}{|c|c|c|c|c|c|}
\hline \multirow[t]{2}{*}{ No } & \multirow[t]{2}{*}{ Spesies } & \multicolumn{4}{|c|}{ Lokasi } \\
\hline & & Tesabela & Oematnunu & Oenansila & Tebole \\
\hline I & RHIZOPHORACEAE & & & & \\
\hline 1 & Rhizopora apiculata & $\sqrt{ }$ & $\sqrt{ }$ & $\sqrt{ }$ & - \\
\hline 2 & Rhizopora mucronata & $\sqrt{ }$ & $\sqrt{ }$ & $\sqrt{ }$ & - \\
\hline 3 & Rhizopora stylosa- & & $\sqrt{ }$ & - & $\sqrt{ }$ \\
\hline 4 & Burguiera gymnorrhiza & $\sqrt{ }$ & - & - & - \\
\hline II & MYRTACEAE & & & & \\
\hline 1 & Osbornia octodanta & $\sqrt{ }$ & - & $\sqrt{ }$ & $\sqrt{ }$ \\
\hline III & AVICENNIACEAE & & & & \\
\hline 1 & Avicennia officinalis & - & - & - & $\sqrt{ }$ \\
\hline 2 & Avicennia marina & $\sqrt{ }$ & $\sqrt{ }$ & $\sqrt{ }$ & \\
\hline IV & RUBIACEAE & & & & \\
\hline 1 & $\begin{array}{l}\text { Scyphiphora } \\
\text { hydrophyllaceae }\end{array}$ & $\sqrt{ }$ & - & $\sqrt{ }$ & - \\
\hline V & COMBRETACEAE & & & & \\
\hline 1 & Lumnitzera racemosa & $\sqrt{ }$ & - & - & - \\
\hline VI & SONNERATIACEAE & & & & \\
\hline 1 & Sonneratia alba & $\sqrt{ }$ & $\sqrt{ }$ & - & $\sqrt{ }$ \\
\hline VII & MYRSINACEAE & & & & \\
\hline 1 & Aegiceras corniculatum & $\sqrt{ }$ & - & - & - \\
\hline & Spesies & 9 & 5 & 4 & 5 \\
\hline & Genus & 8 & 3 & 3 & 4 \\
\hline & Famili & 7 & 3 & 3 & 4 \\
\hline
\end{tabular}

nilai kerapatan tertinggi (870 ind/ha) dan kerapatan relatif $(99,62 \%)$, anakan/pancang dari jenis Osbornia octodanta dengan nilai kerapatan tertinggi (200 ind/ ha) dan kerapatan relatif $(100 \%)$ dan tingkatan semai Rhizophora mucronata yang memiliki nilai kerapatan tertinggi (300 ind/ha) dan kerapatan relatif $(56,60 \%)$. Sedangkan untuk nilai frekwensi berkisar antara 0,33 -1 , dan frekwensi relatif yang beragam. Hasil analisis dominansi menunjukan jenis Rhizophora mucronata memiliki nilai dominansi jenis dan relatif tertinggi sebesar 69,8 (100\%), yang paling rendah adalah jenis Scyphiphora hydrophyllaceae memiliki nilai dominansi jenis dan relatif sebesar $10,90(23,89 \%)$.

\section{d. Tebole}

Pengambilan data penelitian di Tebole dilakukan pada 3 (stasiun) pengamatan, yakni pada koordinat $10,20877^{\circ}$ LS, $123,41962^{\circ}$ BT (Tebole 1), 10,20904 ${ }^{\circ}$ LS, $123,41898^{\circ}$ BT (Tebole 2) dan $10,20857^{\circ}$ LS, $123,42116^{\circ}$ BT (Tebole 3). Hasil anlisis kerapatan, frekuensi dan dominansi jenis-jenis mangrove di Tebole disajikan pada tabel 5 berikut.

Data pada tabel 5 menunjukkan bahwa jenis
Sonneratia alba memiliki nilai kerapatan tertinggi (1.600 ind/ha) dan kerapatan relatif $(56,61 \%)$ untuk tingkatan pohon, sedangkan anakan/pancang dari jenis Sonneratia alba nilai kerapatan tertinggi (200 ind/ ha) dan kerapatan relatif (42,55\%). Selanjutnya untuk tingkatan semai dari jenis Rhizophora stylosa memiliki nilai kerapatan tertinggi (630 ind/ha) dan kerapatan relatif $(49,87 \%)$. Sedangkan untuk nilai frekwensi berkisar antara $0,33-1$, dan frekwensi relatif yang beragam. Hasil analisis dominansi menunjukan jenis Sonneratia alba merupakan jenis mangrove yang memiliki nilai dominansi jenis dan relatif tertinggi sebesar 58,32 (75,23\%), paling rendah dari jenis Rhizophora stylosa memiliki nilai dominansi jenis dan relatif sebesar 1,03 (1,33\%).

\section{Indeks Nilai Penting}

Indeks Nilai Penting (INP) atau Impontant Value Index yang digunakan untuk menetapkan dominansi suatu jenis terhadap jenis lainnya atau dengan kata lain nilai penting menggambarkan kedudukan ekologis suatu jenis dalam suatu komunitas vegetasi atau menunjukkan penguasaan ruang suatu jenis pada suatu tempat. Apabila INP suatu jenis vegetasi bernilai 

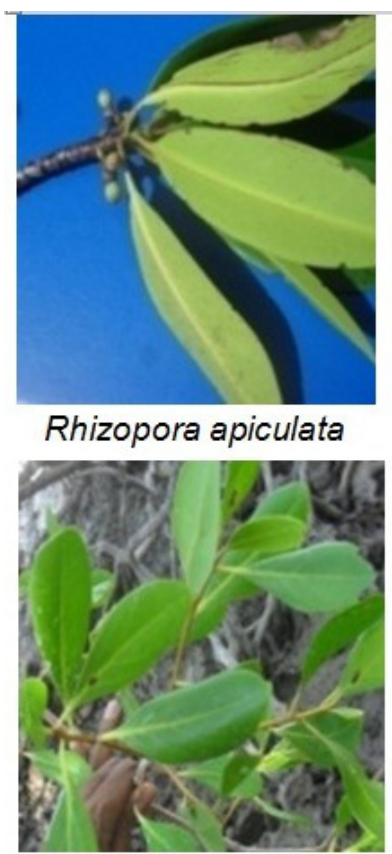

Avicennia officinalis

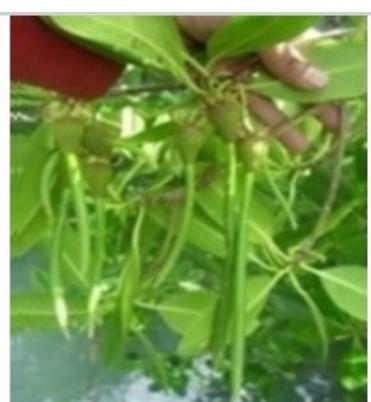

Rhizopora mucronata

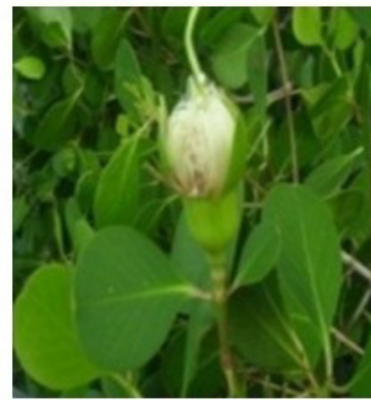

Sonneratia alba

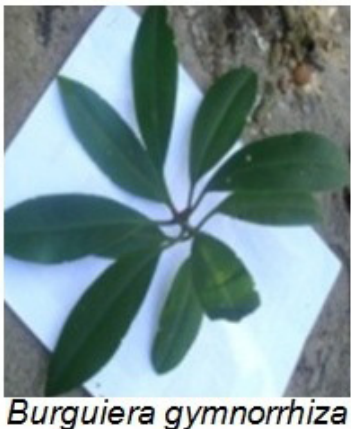

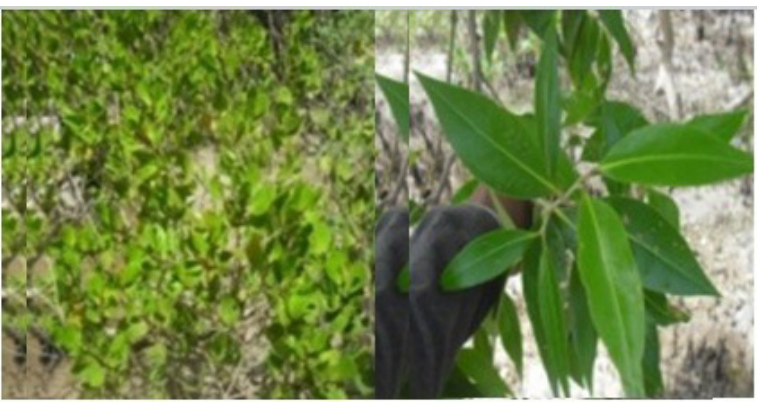

Osbornia octodanta

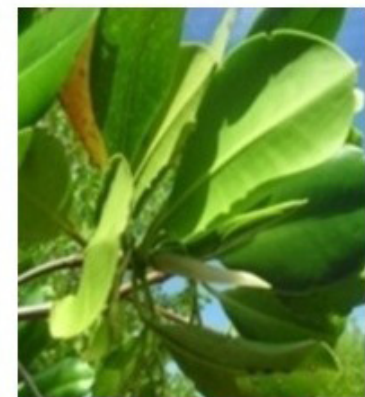

Lumnitcera racemosa

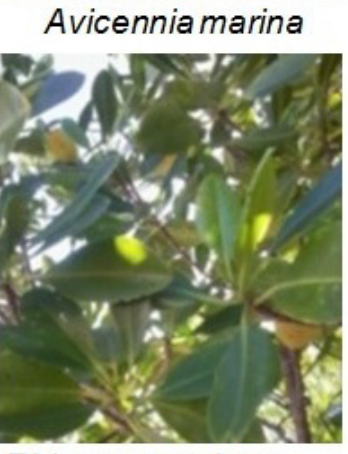

Rhizopora stylosa

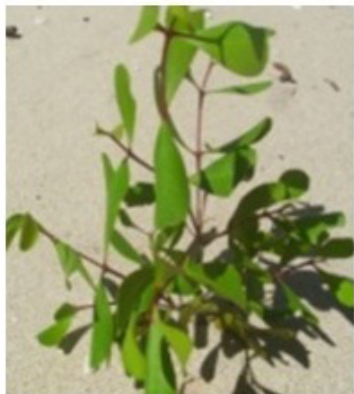

Scyphiphora hydrophyllaceae

Gambar 2. Jenis mangrove yang diperoleh pada 4 (empat) lokasi pengamatan.

tinggi, maka jenis itu sangat mempengaruhi kestabilan ekosistem tersebut (Fachrul, 2007). Adapun hasil analisis Indeks Nilai Penting (INP) yang diperoleh di lokasi penelitian sebagaimana disajikan pada table 6 .

Data pada tabel 6 menunjukkan kisaran nilai INP pohon pada 4 (empat) lokasi penelitian adalah 299,6 - 18,5 dan jenis yang memiliki INP tertinggi yaitu Rhizopora mucronata yang terdapat pada lokasi Oenansila 1 , sedangkan yang memiliki INP terendah adalah Rhizopora stylosa yang terdapat di lokasi Tebole 3. Mangrove tingkatan anakan memiliki kisaran nilai INP 202 - 39,62, yang memiliki INP tertinggi sekaligus terendah adalah Rhizopora apiculata. INP tertinggi terdapat pada lokasi Tesabela 2, sedangkan nilai INP terendah terdapat pada lokasi Oematnunu 1. Sedangkan kisaran nilai INP tingkatan semai adalah 174 - 11,80. Jenis Soneratia alba memiliki indeks nilai penting tertinggi terdapat pada lokasi Tesabela 2 , sedangkan 2 jenis mangrove dengan indeks nilai penting terendah adalah Burguiera gymnorrhiza dan Scyphiphora hydrophyllaceae terdapat di lokasi Tesabela 1
Pola sebaran jenis mangrove tingkatan pohon menunjukkan tidak semua jenis ditemukan pada semua stasiun, yang memiliki pola sebaran yang tinggi adalah jenis Avicennia marina yang ditemukan pada 3 stasiun yakni Tesabela, Oematnunu dan Tebole. Demikian pula pola sebaran jenis mangrove anakan/ pancang dan semai tidak merata, untuk mangrove tingkatan anakan/pancang tidak ditemukan pada beberapa lokasi pengamatan seperti di Oematnunu 2, Oematnunu 3, Oenansila 1 dan Oenansila 2. Sedangkan jenis mangrove tingkatan semai juga tidak ditemukan pada beberapa lokasi pengamatan seperti di Oematnunu 3, Oenansila 1 dan Oenansila 2.

Mangrove merupakan contoh ekosistem yang banyak ditemui di sepanjang pantai tropis dan estuari. Ekosistem ini memiliki fungsi sebagai penyaring bahan nutrisi dan penghasil bahan organik serta berfungsi sebagai daerah penyangga antara daratan dan lautan. Ekosistem mangrove memiliki arti penting sebagai penyedia makanan bagi organisme yang berasosiasi dengan mangrove. Karena itu mangrove perlu dilestarikan, sehingga potensi yang dimiliki 
Tabel 2. Hasil Analisis Kerapatan, Frekuensi dan Dominansi Mangrove di Tesabela

\begin{tabular}{|c|c|c|c|c|}
\hline $\begin{array}{l}\text { Stasiun } \\
\text { Pengamatan }\end{array}$ & Spesies & $\mathrm{K}$ & $\mathrm{F}$ & $\mathrm{D}$ \\
\hline \multirow[t]{12}{*}{ Tesabela 1} & Pohon & & & \\
\hline & Rhizopora mucronata & 0,12 & 1 & 20,62 \\
\hline & Osbornia octodanta & 0,033 & 1 & 21,27 \\
\hline & $\begin{array}{l}\text { Avicennia marina } \\
\text { Anakan }\end{array}$ & 0,02 & 0,67 & 6,58 \\
\hline & Sonneratia alba & 0,01 & 0,33 & \\
\hline & $\begin{array}{l}\text { Scyphiphora hydrophyllaceae } \\
\text { Semai }\end{array}$ & 0,003 & 0,33 & \\
\hline & Rhizopora mucronata & 0,22 & 0,67 & \\
\hline & Osbornia octodanta & 0,007 & 0,33 & \\
\hline & Lumnitzera racemosa & 0,057 & 0,67 & \\
\hline & Sonneratia alba & 0,193 & 0,67 & \\
\hline & Scyphiphora hydrophyllaceae & 0,003 & 0,33 & \\
\hline & Burguiera gymnorrhiza & 0,003 & 0,33 & \\
\hline \multirow[t]{9}{*}{ Tesabela 2} & Pohon & & & \\
\hline & Avicennia marina & 0,003 & 0,33 & 3,23 \\
\hline & Rhizopora apiculata & 0,073 & 0,67 & 19,02 \\
\hline & Aegiceras corniculatum & 0,003 & 0,33 & 0,67 \\
\hline & Osbornia octodanta & 0,003 & 0,33 & 1,23 \\
\hline & $\begin{array}{l}\text { Lumnitzera racemosa } \\
\text { Anakan }\end{array}$ & 0,027 & 0,67 & 7,82 \\
\hline & $\begin{array}{l}\text { Rhizopora apiculata } \\
\text { Semai }\end{array}$ & 0,013 & 0,67 & \\
\hline & Sonneratia alba & 1,033 & 1 & \\
\hline & Lumnitzera racemosa & 0,003 & 0,33 & \\
\hline \multirow[t]{8}{*}{ Tesabela 3} & Pohon & & & \\
\hline & Avicennia marina & 0,003 & 0,33 & 2,67 \\
\hline & Rhizopora mucronata & 0,013 & 0,67 & 7,07 \\
\hline & Osbornia octodanta & 0,003 & 0,33 & 6,17 \\
\hline & $\begin{array}{l}\text { Sonneratia alba } \\
\text { Anakan }\end{array}$ & 0,017 & 0,33 & 10,33 \\
\hline & $\begin{array}{l}\text { Sonneratia alba } \\
\text { Semai }\end{array}$ & 0,03 & 0,33 & \\
\hline & Rhizopora mucronata & 0,06 & 0,33 & \\
\hline & Sonneratia alba & 0,01 & 0,67 & \\
\hline
\end{tabular}

Keterangan; K: Kerapatan, F: Frekwensi dan D: Dominansi

terutama dalam menjaga keseimbangan ekologis dapat dimanfaatkan secara berkelanjutan.

Vegetasi mangrove di 4 (empat) lokasi penelitian merupakan hutan mangrove alami. Vegetasi mangrove yang ditemukan dibedakan antara pohon, anakan/ pancang dan semai. Berdasarkan hasil penelitian (tabel 1) menunjukkan bahwa di 4 (empat) lokasi penelitian diperoleh 11 jenis mangrove yakni; Rhizopora apiculata, Rhizopora mucronata, Rhizopora stylosa, Burguiera gymnorrhiza, Osbornia octodanta,Avicennia officinalis, Avicennia marina, Scyphiphora hydrophyllaceae, Lumnitzera racemosa, Sonneratia albadan Aegiceras corniculatum.

Hasil analisis Indeks Nilai Penting (INP) diperoleh jenis mangrove tertentu yang memiliki INP tertinggi, hal ini berkaitan erat dengan substrat yang dimiliki. Data substrat yang diperoleh pada masing-masing lokasi penelitian yakni; Tesabela (berlumpur, lumpur berpasir dan berpasir), Oematnunu (berlumpur), Oenansila (berlumpur dan lumpur berbatu) dan Tebole (berlumpur). Menurut Chapman (1977) dalam Noor, et al.,1999), bahwa sebagian besar jenis mangrove tumbuh dengan baik pada tanah berlumpur dimana endapan lumpur terakumulasi. Hal ini sejalan dengan pendapat Sukardjo (1996) mengungkapkan bahwa, tumbuh dan berkembangnya setiap jenis mangrove secara konsisten berkaitan dengan tipe substrat, elevasi dan keterbukaan, sehingga spesifikasi tempat tumbuhnya berpengaruh dominan terhadap tipe komunitas dan sekutunya.

Chapman (1984) dalam Sunarto, (2008) 
menyatakan bahwa salah satu faktor yang mempengaruhi perluasan atau penambahan areal mangrove adalah substrat. Mangrove dapat ditemukan dalam pasir, lumpur, dan batuan karang, tetapi mangrove yang paling luas selalu berhubungan dengan tanah berlumpur dan ini banyak ditemukan pada daerah delta, lagun, teluk dan estuaria. Sedangkan Arif (2003) mengatakan substrat adalah tempat dimana akar-akar mangrove dapat tumbuh. Karakteristik substrat yang baik menentukan banyaknya tegakan mangrove yang dapat tumbuh dan berkembang.

Hasil penelitian menunjukkan adanya hubungan erat antara tipe substat dengan jenis mangrove yang hidup didalamnya. Di lokasi Tesabela yang memiliki tipe substrat berlumpur dan berpasir. Di lokasi tersebut ditemukan beberapa spesies diantaranya, $S$. alba dan A.marina. Menurut Indah, et al. (2008) substrat berpasir merupakan substrat yang sangat cocok untuk jenis Avicennia sp dan Sonneratia sp. Faktor arus dalam

Tabel 3.

Hasil Analisis Kerapatan, Frekuensi dan Dominansi Mangrove di Oematnunu

\begin{tabular}{|c|c|c|c|c|}
\hline $\begin{array}{l}\text { Stasiun } \\
\text { Pengamatan }\end{array}$ & Spesies & $\mathrm{K}$ & $\mathrm{F}$ & $\mathrm{D}$ \\
\hline \multirow[t]{10}{*}{ Oematnunu 1} & Pohon & & & \\
\hline & Avicennia marina & 0,05 & 1 & 26,9 \\
\hline & Rhizopora stylosa & 0,033 & 0,67 & 7,533 \\
\hline & $\begin{array}{l}\text { Sonneratia alba } \\
\text { Anakan }\end{array}$ & 0,063 & 0,67 & 14,73 \\
\hline & Rhizopora apiculata & 0,003 & 0,33 & \\
\hline & Rhizopora stylosa & 0,007 & 0,33 & \\
\hline & $\begin{array}{l}\text { Sonneratia alba } \\
\text { Semai }\end{array}$ & 0,043 & 0,33 & \\
\hline & Avicennia marina & 4,78 & 0,33 & \\
\hline & Rhizopora apiculata & 0,07 & 0,33 & \\
\hline & Rhizopora stylosa & 0,71 & 0,67 & \\
\hline \multirow[t]{5}{*}{ Oematnunu 2} & Pohon & & & \\
\hline & Avicennia marina & 0,037 & 0,67 & 20,15 \\
\hline & Rhizopora apiculata & 0,003 & 0,33 & 1,633 \\
\hline & $\begin{array}{l}\text { Rhizopora stylosa } \\
\text { Semai }\end{array}$ & 0,067 & 0,67 & 34,32 \\
\hline & Rhizopora apiculata & 0,067 & & 0,333 \\
\hline \multirow[t]{4}{*}{ Oematnunu 3} & Pohon & & & \\
\hline & Sonneratia alba & 0,057 & 1 & 36,78 \\
\hline & Avicennia marina & 0,037 & 1 & 21,37 \\
\hline & Rhizopora mucronata & 0,127 & 1 & 109,9 \\
\hline
\end{tabular}

Keterangan; K: Kerapatan, F: Frekwensi dan D: Dominansi

Tabel 4 .

Hasil Analisis Kerapatan, Frekuensi dan Dominansi Mangrove di Oenansila

\begin{tabular}{lllll}
\hline $\begin{array}{l}\text { Stasiun } \\
\text { Pengamatan }\end{array}$ & Spesies & K & F & D \\
\hline Oenansila 1 & Pohon & & & \\
& $\begin{array}{l}\text { Rhizopora mucronata } \\
\text { Oenansila 2 }\end{array}$ & 0,087 & 1 & 69,8 \\
& $\begin{array}{l}\text { Pohon } \\
\text { Rhizopora apiculata }\end{array}$ & 0,04 & 0,33 & 26,17 \\
& Rhizopora mucronata & 0,08 & 0,67 & 33,7 \\
& Pohon & & & \\
& Rhizopora apiculata & 0,03 & 0,33 & 17,33 \\
& Rhizopora mucronata & 0,04 & 0,67 & 17,4 \\
& Scyphiphora hydrophyllaceae & 0,04 & 0,33 & 10,9 \\
& Anakan & & & \\
& Osbornia octodonta & 0,02 & 0,67 & \\
& Semai & & & \\
& Rhizopora apiculata & 0,003 & 0,33 & \\
& Rhizopora mucronata & 0,03 & 0,67 & \\
& Osbornia octodonta & 0,02 & 0,67 & \\
\hline
\end{tabular}

Keterangan; K: Kerapatan, F: Frekwensi dan D: Dominansi 
Tabel 5. Hasil Analisis Kerapatan, Frekuensi dan Dominansi Mangrove di Tebole

\begin{tabular}{|c|c|c|c|c|}
\hline $\begin{array}{l}\text { Stasiun } \\
\text { Pengamatan }\end{array}$ & Spesies & $\mathrm{K}$ & $\mathrm{F}$ & $\mathrm{D}$ \\
\hline \multirow[t]{9}{*}{ Tebole 1} & Pohon & & & \\
\hline & Sonneratia alba & 0,053 & 1 & 37,93 \\
\hline & Avicennia marina & 0,04 & 1 & 14,5 \\
\hline & Avicennia alba & 0,007 & 0,33 & 4,81 \\
\hline & $\begin{array}{l}\text { Osbornia octodonta } \\
\text { Anakan }\end{array}$ & 0,003 & 0,33 & 1,9 \\
\hline & Avicennia marina & 0,003 & 0,33 & \\
\hline & $\begin{array}{l}\text { Rhizopora stylosa } \\
\text { Semai }\end{array}$ & 0,013 & 0,33 & \\
\hline & Avicennia alba & 0,003 & 0,33 & \\
\hline & Osbornia octodonta & 0,003 & 0,33 & \\
\hline \multirow[t]{10}{*}{ Tebole 2} & Pohon & & & \\
\hline & Rhizopora stylosa & 0,04 & 0,33 & 5,95 \\
\hline & Sonneratia alba & 0,16 & 1 & 42,2 \\
\hline & $\begin{array}{l}\text { Avicennia marina } \\
\text { Anakan }\end{array}$ & 0,11 & 1 & 19,07 \\
\hline & Rhizopora stylosa & 0,013 & 0,67 & \\
\hline & Sonneratia alba & 0,02 & 0,67 & \\
\hline & $\begin{array}{l}\text { Avicennia marina } \\
\text { Semai }\end{array}$ & 0,013 & 0,33 & \\
\hline & Rhizopora stylosa & & 0,063 & 0,67 \\
\hline & Sonneratia alba & & 0,023 & 0,33 \\
\hline & Avicennia marina & & 0,04 & 1 \\
\hline \multirow[t]{9}{*}{ Tebole 3} & Pohon & & & \\
\hline & Rhizopora stylosa & 0,003 & 0,33 & 1,03 \\
\hline & Sonneratia alba & 0,093 & 1 & 58,32 \\
\hline & $\begin{array}{l}\text { Avicennia marina } \\
\text { Anakan }\end{array}$ & 0,037 & 1 & 18,17 \\
\hline & Rhizopora stylosa & 0,003 & 0,33 & \\
\hline & Avicennia marina & 0,01 & 0,33 & \\
\hline & $\begin{array}{l}\text { Osbornia octodonta } \\
\text { Semai }\end{array}$ & 0,013 & 0,33 & \\
\hline & Rhizopora stylosa & 0,003 & 0,33 & \\
\hline & Osbornia octodonta & 0,017 & 0,33 & \\
\hline
\end{tabular}

Keterangan; K: Kerapatan, F: Frekwensi dan D: Dominansi

keadaan pasang dan surut sangat mempengaruhi terbentuknya substrat.

Sedangkan di Oematnunu dan Tebole memiliki tipe substrat berlumpur. Di lokasi tersebut ditemukan beberapa spesies mangrove diantaranya, $R$. mucronata. Menurut Poedjirahajoe, (1966) Substrat jenis lempung berpasir atau berlumpur memang merupakan substrat yang sangat cocok untuk tempat tumbuhnya jenis Rhizopora sp. Pembentukan substrat ini sangat dipengaruhi oleh adanya arus dalam keadaan pasang dan surut yang membawa partikelpartikel yang diendapkan pada saat surut.

Dominasi dan tingginya indeks nilai penting (INP) jenis mangrove tertentu di lokasi penelitian karena karakteristik lokasi penelitian yang sesuai dengan karakteristik yang diinginkan oleh jenis mangrove tersebut, karena menurut (Kint, 1934 dalam Noor et al.,
1999) di Indonesia, substrat berlumpur ini sangat baik untuk tegakan Rhizophora mucronata dan Avicennia officinalis. Dikatakan pula bahwa jenis tertentu seperti Rhizophora stylosa dan Sonneratia alba tumbuh baik pada substrat berpasir atau bahkan pada pantai berbatu.

Pola zonasi mangrove di lokasi penelitian menunjukkan pola zonasi yang beragam, di Oematnunu 1, memiliki pola zonasi dimana jenis mangrove yang tumbuh pada bagian paling depan (berhaapan langsung dengan laut) adalah jenis Avicennia spp berasosiasi dengan Sonneratia dan jenis mangrove yang tumbuh pada bagian paling luar adalah jenis Rhizophora spp, pola zonasi ini hampir sama dengan pola zonasi mangrove yang tumbuh di lokasi Tebole. Sedang pola zonasi yang berbeda terdapat di Oematnunu 2, Oematnunu 3, dimana jenis mangrove yang berada di bagian terdepan adalah 
Tabel 6.

Hasil Analisis INP mangrove untuk tingkatan pohon, anakan dan semai

\begin{tabular}{|c|c|c|c|c|c|c|c|c|c|c|c|c|c|}
\hline \multirow{2}{*}{$\begin{array}{l}\text { Tingkatan } \\
\text { Vegetasi }\end{array}$} & \multirow{2}{*}{ Lokasi } & \multirow{2}{*}{ Stasiun } & \multicolumn{11}{|c|}{ Spesies } \\
\hline & & & A & B & C & D & $\mathrm{E}$ & $\mathrm{F}$ & G & $\mathrm{H}$ & I & J & K \\
\hline \multirow{13}{*}{$\begin{array}{l}\text { Tingkatan } \\
\text { Pohon }\end{array}$} & \multirow{4}{*}{ Tesabela } & 1 & - & 149,4 & - & - & 100,6 & - & 50,14 & - & - & - & - \\
\hline & & 2 & 154,8 & - & - & - & 21,19 & - & 27,45 & - & 77,3 & - & 19,42 \\
\hline & & 3 & - & 102,9 & - & - & 52,48 & - & 39,14 & - & - & 104,4 & - \\
\hline & & 1 & - & - & 66,61 & - & - & - & 131,6 & - & - & 101,7 & - \\
\hline & \multirow[t]{3}{*}{ Oematnunu } & 2 & 25,99 & - & 163,4 & - & - & - & 110,1 & - & - & - & - \\
\hline & & 3 & - & 156,3 & - & - & - & - & 62,71 & - & - & 80,97 & - \\
\hline & & 1 & - & 299,6 & - & - & - & - & - & - & - & - & - \\
\hline & \multirow[t]{3}{*}{ Oenansila } & 2 & 110,4 & 186,8 & - & - & - & - & - & - & - & - & - \\
\hline & & 3 & 77.54 & 107.1 & - & - & - & - & - & 66,34 & - & - & - \\
\hline & & 1 & - & - & - & - & 18,93 & 27,09 & 100,8 & - & - & 153,4 & - \\
\hline & \multirow[t]{3}{*}{ Tebole } & 2 & - & - & 36,06 & - & - & - & 106,8 & - & 157,3 & - & - \\
\hline & & 3 & - & - & 18,15 & - & - & - & 93,92 & - & - & 188,3 & - \\
\hline & & 1 & - & - & - & - & - & - & - & 75.62 & - & 126.9 & - \\
\hline \multirow{7}{*}{$\begin{array}{c}\text { Tingkatan } \\
\text { Anakan }\end{array}$} & \multirow[t]{2}{*}{ Tesabela } & 2 & 202 & - & - & - & - & - & - & - & - & - & - \\
\hline & & 3 & - & - & - & - & - & - & - & - & - & 201 & - \\
\hline & Oematnunu & 1 & 39,62 & - & 45,91 & - & - & - & - & - & - & 115,1 & - \\
\hline & \multirow[t]{2}{*}{ Oenansila } & 3 & - & - & - & - & 200 & - & - & - & - & - & - \\
\hline & & 1 & - & - & 128,2 & - & - & - & 69,36 & - & - & - & - \\
\hline & \multirow[t]{3}{*}{ Tebole } & 2 & - & - & 68,29 & - & - & - & 48,33 & - & - & 82,47 & - \\
\hline & & 3 & - & - & 45,68 & - & 82,72 & - & 70,37 & - & - & - & - \\
\hline \multirow{9}{*}{$\begin{array}{c}\text { Tingkatan } \\
\text { Semai }\end{array}$} & & 1 & - & 67,77 & - & 11,8 & 12,49 & - & - & 11,8 & 33,95 & 62,25 & - \\
\hline & \multirow[t]{2}{*}{ Tesabela } & 2 & - & - & - & - & - & - & - & - & 25,38 & 174,8 & - \\
\hline & & 3 & - & 119 & - & - & - & - & - & - & - & 76.19 & - \\
\hline & \multirow[b]{2}{*}{ Oematnunu } & 1 & 26,26 & - & 62,9 & - & - & - & 111 & - & - & - & - \\
\hline & & 2 & 167 & - & - & - & - & - & - & - & - & - & - \\
\hline & \multirow[t]{2}{*}{ Oenansila } & 3 & 26,25 & 96,52 & - & - & 77,66 & - & - & - & - & - & - \\
\hline & & 1 & - & - & - & - & 97,73 & 97,73 & - & - & - & - & - \\
\hline & \multirow[t]{2}{*}{ Tebole } & 2 & - & - & 83,2 & - & & - & 81,5 & - & - & 35,04 & - \\
\hline & & 3 & - & - & 66,42 & - & 133,1 & - & - & - & - & - & - \\
\hline \multicolumn{3}{|c|}{ Keterangan spesies; } & \multicolumn{11}{|c|}{$\begin{array}{l}\text { A; Rhizopora apiculata, B; Rhizopora mucronata, C; Rhizopora } \\
\text { stylosa, D; Burguiera gymnorrhiza, E; Osbornia octodanta, F; } \\
\text { Avicennia officinalis, G; Avicennia marina, H; Scyphiphora } \\
\text { hydrophyllaceae, I; Lumnitzera racemosa, J; Sonneratia alba, } \\
\text { K; Aegiceras corniculatum }\end{array}$} \\
\hline
\end{tabular}

jenis Rhizophora spp, diikuti oleh jenis Avicennia spp dan Sonneratia, dan jenis mangrove yang paling belakang kembali ditemukan jenis Rhizophora spp yang dibeberapa lokasi (Oenansila dan Tesabela) jenis Rhizophora spp beraosiasi dengan jenis Osbornia octodanta. Pola zonasi yang terbentuk secara umum diketahui bahwa zonasi yang terbentuk memiliki beberapa model yang berbeda pada setiap lokasi di setiap daerah, sebagaimana Nyabakken (1992) menyatakan bahwa tidak ada model (pola zonasi) yang berlaku secara universal. Noor, et al. (1999) juga mengatakan bahwa kenyataan di lapangan menunjukkan banyak formasi serta zona vegetasi yang tumpang tindih dan bercampur serta seringkali struktur dan korelasi yang nampak di suatu daerah tidak selalu dapat diaplikasikan di daerah yang lain.

Pola zonasi hutan mangrove terbentuk karena adanya pengaruh dari beberapa faktor lingkungan. Faktor-faktor yang mempengaruhi zonasi hutan mangrove adalah salinitas, $\mathrm{pH}$, oksigen terlarut, arus, kekeruhan, toleransi terhadap ombak dan angin, toleransi terhadap lumpur (substrat dasar) dan frekuensi genangan air (Bengen \& Dutton, 2002 dalam Northcote \& Hartman, 2004; Nybakken, 1992).
Faktor substrat turut mempengaruhi komposisi jenis mangrove, nilai kerapatan, frekuensi dan dominansi jenis mangrove yang terdapat dalam suatu komunitas mangrove dilokasi penelitian. Hal ini dibuktikan dari jenis-jenis mangrove yang menempati komunitas mangrove pada 4 (empat) lokasi penelitian ternyata ada perbedaan pada komposisi jenis mangrove, nilai kerapatan, frekuensi, dominansi dan Indeks Nilai Penting (INP) dari masing-masing jenis mangrove. Hal tersebut sejalan dengan pendapat yang mengatakan bahwa karakteristik tanah merupakan faktor utama yang membatasi pertumbuhan dan distribusi tanaman mangrove (Aksornkoae et al, 1985 dalam Aksornkoae, 1993).

Hutan mangrove di lokasi penelitian juga menunjukkan adanya tanda-tanda kerusakan, yang diakibatkan oleh aktivitas manusia terutama vegetasi mangrove yang letaknya berdekatan dengan tempat tinggal atau pusat aktivitas penduduk seperti di Tesabela dan Oematnunu karena di 2 (dua) lokasi tersebut berdekatan dengan pusat aktivitas masyarakat (budidaya rumput laut). Di dua tempat tersebut ditemukan beberapa jenis mangrove yang ditebang atau dimanfaatkan oleh masyarakat. Apabila hal seperti ini dibiarkan terus-menerus, bukan tidak mungkin 
hutan mangrove yang ada saat ini sedikit demi sedikit akan terkikis atau bahkan punah. Pemanfaatan kayu mangrove seperti ini yang menyebabkan hilangnya vegetasi mangrove, sebagaimana yang dikatakan Aksornkoae (1993) bahwa saat ini di seluruh dunia terjadi peningkatan hilangnya sumberdaya mangrove yangdisebabkan adanya pemanfaatan yang tidak berkelanjutan serta pengalihan peruntukan

\section{KESIMPULAN DAN SARAN}

\section{Kesimpulan}

Berdasarkan hasil penelitian dan analisis di atas, dapat disimpulkan bahwa jenis mangrove yang ditemukan pada 4 (empat) lokasi penelitian sebanyak 11 jenis yakni; Rhizopora apiculata, Rhizopora mucronata, Rhizopora stylosa, Burguiera gymnorrhiza, Osbornia octodanta, Avicennia officinalis, Avicennia marina, Scyphiphora hydrophyllaceae, Lumnitzera racemosa, Sonneratia alba dan Aegiceras corniculatum. Jenis mangrove yang memiliki indeks nilai penting tertinggi untuk tingkatan pohon yaitu Rhizopora mucronata (INP $: 299,6)$ dan terendah adalah Rhizopora stylosa (INP : $18,5)$, untuk tingkatan pancang/anakan jenis mangrove yang memiliki indeks nilai penting tertinggi sekaligus terendah adalah Rhizopora apiculata (INP : 202 dan 39,62). Sedangkan untuk tingkatan semai, jenis yang memiliki indeks nilai penting tertinggi yaitu Soneratia alba (INP : 174)dan terendah adalah Burguiera gymnorrhiza dan Scyphiphora hydrophyllaceae (INP : 11,80).

\section{Saran}

Berdasarkan hasil penelitian dan analisis serta pembahasan di atas, maka ada beberapa hal yang perlu diperhatikan sebagai bahan pertimbangan :

1. Perlu dilakukan kajian, pengamatan dan telaahan yang kontinu dan berkelanjutan tentang kondisi hutan mangrove, khususnya dilokasi penelitian saat ini (Tesabela, Oematnunu, Oenansila dan Tebole)

2. Perlu dilakukan upaya pencegahan terhadap kerusakan dan berkurang atau bahkan hilangnya hutan mangrove melalui peningkatan kapasitas dan pemahaman masyarakat khususnya yang berada disekitar hutan mangrove tentang arti penting dan peranan hutan mangrove bagi kelangsungan hidup manusia dan organisme lainnya.

\section{PERSANTUNAN}

Terima kasih disampaikan kepada PT. Timor Otzuki Mutiara (PT. TOM) atas bantuan dana yang diberikan untuk pelaksanaan kegiatan penelitian ini. Terima kasih pula disampaikan kepada Lembaga Penelitian, Pengkajian dan Pengabdian kepada
Masyarakat Universitas Muhammadiyah Kupang atas dukungan morilnya memberikan ijin penelitian.

\section{DAFTAR PUSTAKA}

Aksornkoe. (1993). Ecology and management of mangrove. IUCN. Bangkok. Thailand

Arief, A. (2003). Hutan Mangrove Fungsi Dan Manfaatnya. Kanisius. Yogyakarta.

Bengen. D. G. \& Dutton, I.M. (2004). Interaction: mangroves, fisheries and forestry management in Indonesian. H. 632-653. Dalam Northcote. T. G. dan Hartman (Ed), 2004. Worldwide watershed interaction and management. Blackwell science.. Oxford. UK.

Bengen, D. G. (2003). Pedoman teknis: Pengenalan dan pengelolaan ekosistem mangrove. PKSPLIPB. Bogor.

Dahuri. R. (2003). Keanekaragaman Hayati Laut - Aset Pembangunan Berkelanjutan Indonesia. Penerbit PT. Gramedia Pustaka Utama. Jakarta.

Darsidi, A. (1986). Perkembangan pemanfaatan hutan mangrove di Indonesia. Prosiding Seminar II Ekosistem Mangrove. Denpasar, Bali. 5-8 Agustus 1986

Fachrul, M.F. (2007). Metode Sampling Bioekologi. Bumi Aksara. Jakarta

Indah, R., A. Jabarsyah \& Laga, A. (2008). Perbedaan Substrat dan Distribusi Jenis Mangrove (Studi Kasus : Hutan Mangrove Di Kota Tarakan). Fakultas Perikanan dan Kelautan Universitas Borneo. Tarakan.

Irwanto. (2006). Keanekaragaman Fauna pada Habitat Mangrove. Online. http://www.irwantoshut.com (12/07/2014)

Kusmana, C. (1995). Manajemen hutan mangrove Indonesia. Lab Ekologi Hutan. Jurusan Manajemen Hutan, Fakultas Kehutanan, IPB. Bogor.

Kusuma, L.P.A.S.C., \& Suhendra, D. (2006). Komunitas Mangrove di Kawasan Pesisir Teluk Kupang. Pusat Riset Teknologi Kelautan Badan Riset Kelautan dan Perikanan. DKP. Jakarta.

Kusmana, C. (1995). Manajemen Hutan Mangrove Indonesia. Lab Ekologi Hutan. Jurusan Manajemen Hutan, Fakultas Kehutanan, IPB. Bogor 
Noor, Y.R., Khazali, R. \& Suryadiputra I.N.N. (1999). Panduan Pengenalan Mangrove Di Indonesia. PHKA/WI-IP, Bogor.Wetlands InternationalIndonesian Programme

Nybakken, J. W. (1992). Biologi Laut : Suatu pendekatan ekologis (Terjemahan oleh : $M$. Eidman, Koessoebiono dan D. G. Bengen, M. Hutomo dan Sukristijono). Penerbit PT. Gramedia. Jakarta. Indonesia.

Podjirahajoe. (1966). Peran Perakaran Rhizopora mucronata Dalam Perbaikan Habitat Mangrove di Kawasan Rehabilitasi Mangrove Pantai Pemalang. Buletin Kehutanan No. 30 Fakultas Kehutanan, UGM, Yogyakarta.

Rusydi. (2010). Base line Data Kualitas Air dan Biota Perairan di Teluk KupangSebelum Pengoperasian PLTU di Bolok Kecamatan Kupang Barat. Laporan Penelitian. Pusat Penelitian Lingkungan Pesisir, Laut dan Pulau-Pulau Kecil. Unmuh Kupang.

Sukardjo, S. (1996). Gambaran umum ekologi mangrove di Indonesia. Lokakarya Strategi Nasional Pengelolaan Hutan Mangove di Indonesia. Departemen Kehutanan, Direktorat Jenderal Reboisasi dan Rehabilitasi Lahan. Jakarta 26-27 Juni 1996.

Sunarto. (2008). Peranan Ekologis dan Antropogenis Ekosistem Mangrove. Fakultas Perikanan Universitas Padjajaran. 
J. Segara Vol. 11 No. 1 Agustus 2015: 47-56 